\title{
Morphometric Analysis of Major Watersheds in Barind Tract, Bangladesh: A Remote Sensing and GIS-Based Approach for Water Resource Management
}

\author{
Mohammad Ferozur Rahaman ${ }^{1}$, Chowdhury Sarwar Jahan ${ }^{2, *}$, Riad Arefin ${ }^{2}$, \\ Quamrul Hasan Mazumder ${ }^{2}$ \\ ${ }^{1}$ Institute of Environmental Science, University of Rajshahi, Rajshahi, Bangladesh \\ ${ }^{2}$ Department of Geology \& Mining, University of Rajshahi, Rajshahi, Bangladesh

\section{Email address:} \\ feroz90ru@gmail.com (M. F. Rahaman), sarwar_geology@yahoo.com (C. S. Jahan), riad.gmru@gmail.com (R. Arefin), \\ qhm27@yahoo.com (Q. H. Mazumder) \\ *Corresponding author
}

\section{To cite this article:}

Mohammad Ferozur Rahaman, Chowdhury Sarwar Jahan, Riad Arefin, Quamrul Hasan Mazumder. Morphometric Analysis of Major Watersheds in Barind Tract, Bangladesh: A Remote Sensing and GIS-based Approach for Water Resource Management. Hydrology. Vol. 8, No. 6, 2017, pp. 86-95. doi: 10.11648/j.hyd.20170506.12

Received: October 5, 2017; Accepted: October 23, 2017; Published: January 10, 2018

\begin{abstract}
Morphometric analysis of major watersheds based on satellite images using hydrological module of ARC GIS software in the drought prone Barind Tract in the north-western part of Bangladesh has been carried out for its relevance in the water resource management. Here meteorological and hydrological drought effects increase day by day along with demand for groundwater irrigation, turning the area into acute agricultural drought condition. The studied watersheds have stream orders ranging from $1^{\text {st }}$ to $6^{\text {th }}$, show dendritic drainage pattern, and represent homogeneity of soil texture; possibility of flash flood after heavy rainfall with low discharge of runoff; and not largely affected by structural disturbance. The moderate drainage density indicates semi-permeable soil lithology with moderate vegetation. Elongated shape watersheds are with low to moderate relief and are bounded in the east by land area of the Barind Tract of moderate to steep slope. It reveals a flatter peak of runoff flow for longer duration and gravity flow of water. Flat to gentle but undulating slope of the watersheds represent good category for water resource management owing to favorable site for infiltration due to maximum time of runoff water percolation. The east facing slopes of the watersheds show higher moisture contents and higher vegetation. The major part of the watersheds comes under cultivated land which supports the future basin development and management for water resource. Finally, present study would be useful in categorization of watersheds for future water resource development and management, and selection of suitable sites for water conservation structures like check dam, percolation tank etc., and artificial recharge of groundwater through MAR technique.
\end{abstract}

Keywords: Morphometric Analysis, Watershed, Water Resource Management, Drought Prone Barind Tract, Bangladesh

\section{Introduction}

Bangladesh is one of the most disaster-prone countries in the world. Almost every year, the country experiences disasters of one kind, another or a cruel combination of more extremes such as floods, droughts, tropical cyclones, etc. causing heavy loss of life and property and jeopardizing the country's development activities. The extreme weather events along with high population density, poverty level and social inequity, inadequate financial resources etc. have made Bangladesh highly vulnerable to disaster. Since independence in 1971, the country has suffered from nine droughts of major magnitude, but its devastating nature has attracted far less scientific attention than floods or cyclones, because the losses from drought are likely to be more severe than those of floods. Moreover, drought has impact on water resources; hence understanding the drought phenomena have implication in this resources management. Water resource management is indicated to remain at the core of sustainable 
development in the 1992 Rio World Summit on the United Nation Conference on Environment and Development (UNCED) and thus, they are to be managed and developed on a sustainable basis. The National Water Management Plan (NWMP) in Bangladesh considers drought as a major water deficiency issue in the agro-based northwest part popularly known as Barind area (Figure 1) - the granary where livelihood is at risk due to loss of food production, scarcity of drinking water etc. more severely when monsoon is curtailed $[1,2]$.

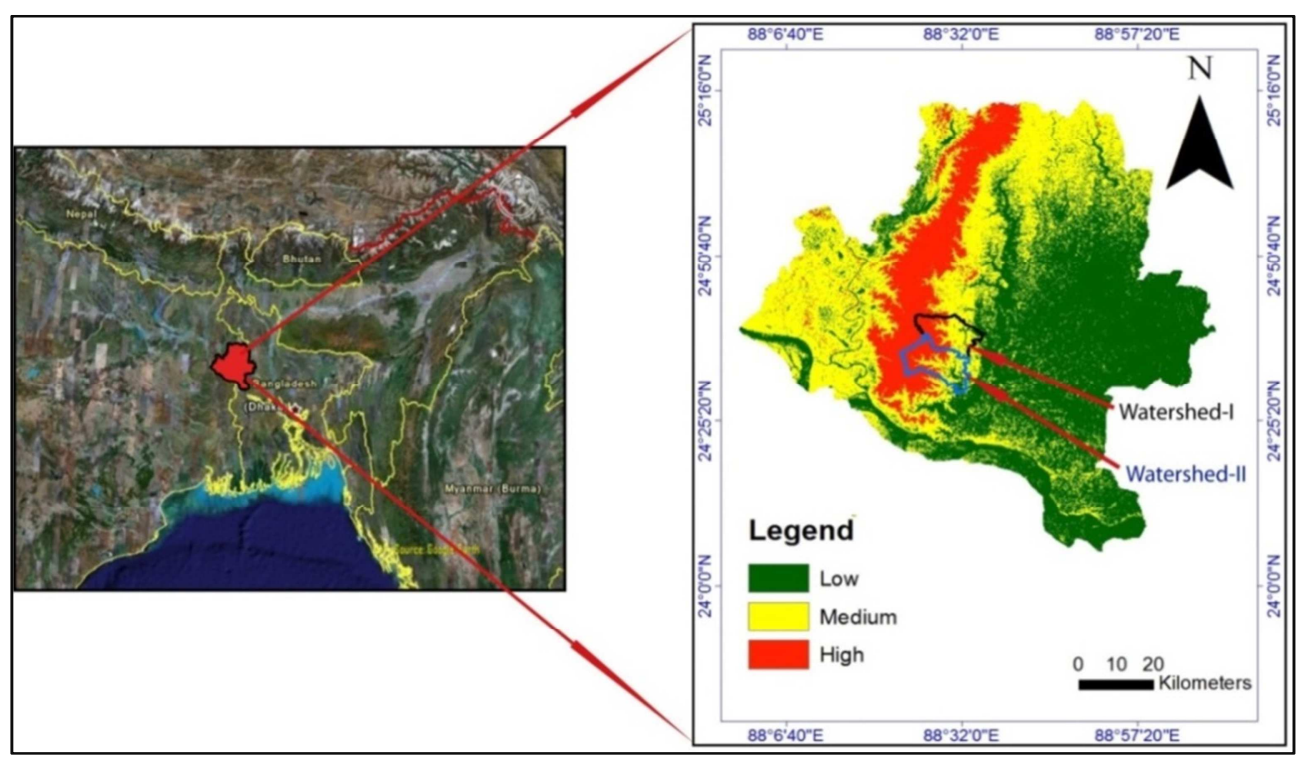

Figure 1. Location map of the Barind Tract, Bangladesh.

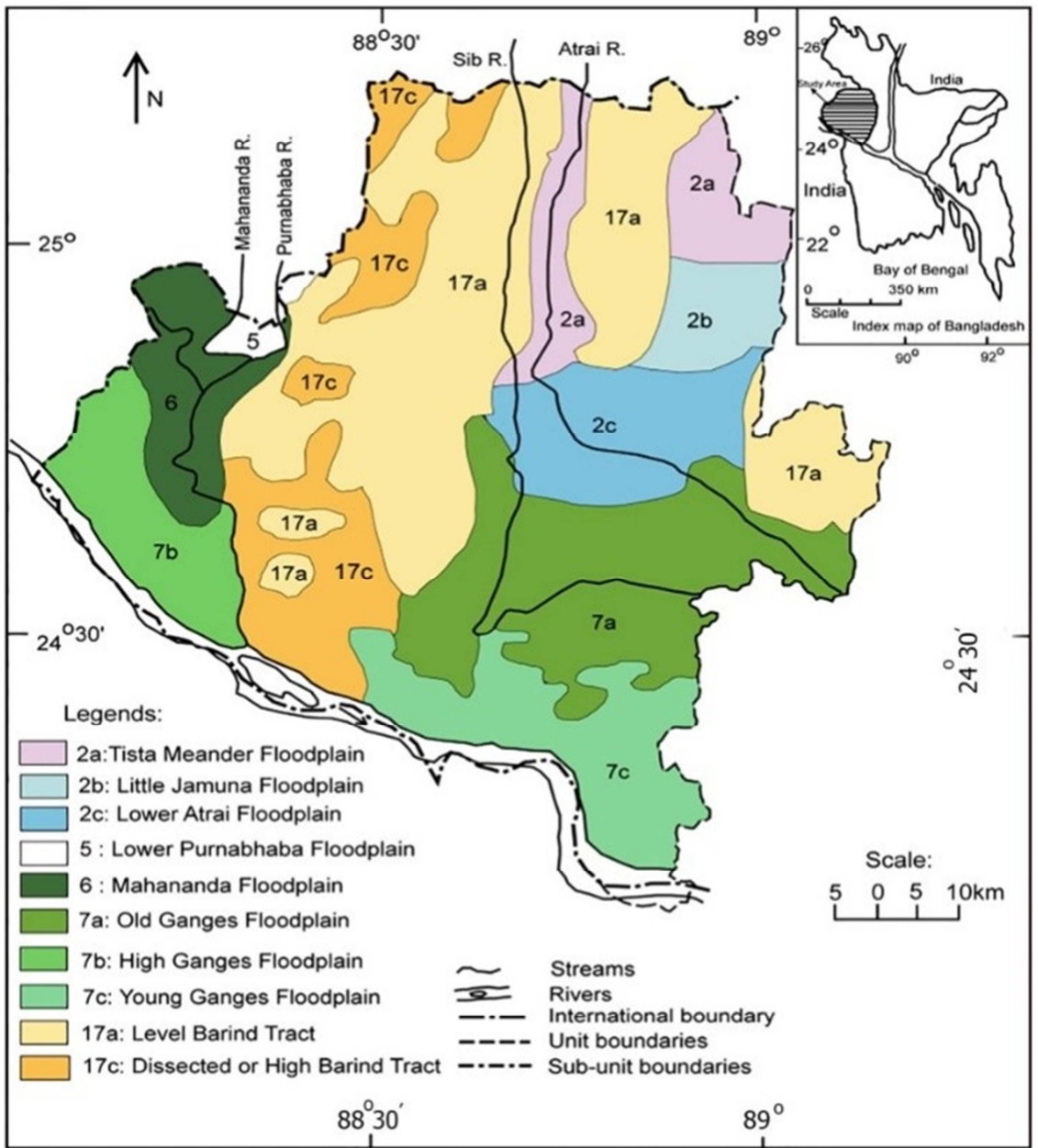

Figure 2. Physiographic map of the Barind area [1, 5]. 
Physiography of the Barind area is characterized by two distinct landforms: the Barind Tract and the floodplains. According to [3] the Barind Tract is one of the oldest Pleistocene terraces, north-south dome shaped area (20-25 $\mathrm{km}$ wide in east-west direction) and covered by older Pleistocene sediments, popularly known as 'Barind Clay'. The elevation of the Tract varies from $47.0 \mathrm{~m}$ above MSL in its central part to $11.0 \mathrm{~m}$ in the southeastern floodplain area. Khandoker [4] shows that the Tract was elevated as horst block at the close of Pleistocene. The physiographic map of the Barind area is shown in Figure 2.

The Barind area enjoys mainly three seasons: winter (NovFeb) - cool and dry with almost no rainfall; pre-monsoon (Mar-May) - hot and dry; and monsoon (Jun-Oct) - rainy. The average annual rainfall for the period of 1980-2012 in the area is $1525 \mathrm{~mm}$ (much less than the national average of $2550 \mathrm{~mm}$ ), where the magnitude of change of annual rainfall shows a significantly decreasing trend (20-23 mm/year) [6]. The monthly average temperature for the same period ranges from $10^{\circ} \mathrm{C}$ (January) to $33^{\circ} \mathrm{C}$ (May) with increasing rate of $0.0208^{\circ} \mathrm{C} /$ year. The moderate to high meteorological drought risk conditions prevail here that creeps towards semi-aridity in recent years [7]. As the area is characteristically recipient of less amount of rainfall; low infiltration capacity of soil insufficient for groundwater recharge; limited scope to conserve rainwater in canals, swamps (beels) and existence of potential aquifer at greater depth for large scale groundwater development makes water scarce zone $[8,9]$.

The Barind Integrated Area Development Project (BIADP) and later the Barind Multipurpose Development Authority (BMDA) was launched during late eighties of the last century in the Barind area in order to achieve sustainable agricultural growth and to maintain ecological balance. Here the groundwater is the main source of irrigation, with exploitation through Deep Tube Wells (DTWs) and Shallow Tube Wells (STWs) [9]. The area has a scope for groundwater withdrawal by 8,728 DTWs of 2-cusec capacity, but at present groundwater is withdrawing through almost 15,000 DTWs by BMDA and another nearly 8,000 by private owners [10]. As the demand of groundwater irrigation increases day by day along with drought intensity, the stress on this resource increases and becoming acute due to overexploitation of groundwater with the extension of irrigated agriculture. The recent declining trend of the groundwater table (GWT) is at higher rate than earlier and after 2002-2004 GWT did not return to its original level [6]. Moreover, the changing climatic scenario along with yearly irregular frequency and intensity of rainfall makes it difficult for planed management of water resource [11]. So there is an urgent need of management of water resources in the area for the sustainability of livelihood and ecosystem.

There is a huge scope to study water resource management issues especially in developing countries where water resources for agriculture is at risk due to unplanned development, low economic capacity to solving the problems, and lack of adaptation measure. As a result the ecosystems are falling at fragile condition that would become irrecoverable without taking action at right time. In this context, water resource management based on morphometric analysis play an important role to understand the physiographic status of the area using remote sensing (RS) and geographical information system (GIS). But unfortunately till now no such studies have been carried out in the study area. So the aim of the present study is to identify prevailing morphometric parameters of the major watersheds in the drought prone Barind Tract with a view for water resource management in the sustainable way. There are several watershed or drainage basins of different stream order in the Tract. But for the present study only two major watersheds (watershed-I and II) (Figure 1) have taken into consideration as they have the highest number of stream orders i.e. $1^{\text {st }}$ to $6^{\text {th }}$ order because here the watersheds or drainage basins have the highest number of stream order (i. e. up to $6^{\text {th }}$ order). At large the ultimate goal of the present study will help to create scientific basis for water resource managers to rain water/ runoff water harvesting in this water scarce area through the potentiality study of construction of water conservation structures like check dam, storage tanks, recharge shaft etc.

\section{Methodology}

The development of drainage network in a watershed depends on the surface and near surface geology that controls the flow and storage management of run-off water; rainfall availability as a source of water; drainage characteristics for the distribution of runoff; infiltration behavior both vertically and horizontally; slope of the area influences water flow energy etc. [12-17]. The morphometric analysis of the studied watersheds in the Barind Tract needs detail information of morphometric parameters like topography, drainage network, channel length etc., geomorphologic, and geological setup for watershed management and plan for water conservation measures based on satellite images and GIS technique. The storage capacity of surface clay in the study area for rain and runoff water flow are obtained from morphometric analysis which provides the yielding capacity of the watersheds to increase its holding capacity of water at drainage basin level [18-20] for water resource management plan.

The Digital Elevation Models (DEMs) obtained from the Shuttle Radar Topography Mission (SRTM) [21, 22] [US Geological Survey website (www. earthexplorar.usgs.gov update 2014 with $30 \mathrm{~m}$ resolution)] is used to extract different morphometric parameters of the studied watersheds i.e. watershed-I and II. Here, an integrated approach of multispectral satellite data, DEM and topographical sheets of the Survey of Bangladesh (SoB) are used for database preparation and analyze morphometric parameters of the watersheds. The data type and their source along with software used in present study are given in Table 1. 
Table 1. Type of data and software used in present study.

\begin{tabular}{lll}
\hline Type of data/software & Details of data & Source \\
\hline SoB topographical sheets & Topographical sheets 78D/5, 6, 9, 10,13 (Scale: $1: 50000)$ & Survey of Bangladesh \\
Landsat 8 satellite imagery & Path/row: 138/42, 138/43, 139/42, 139/43 (December, 2014) & https:/landsat.usgs.gov \\
SRTM DEM & 1-ArcSecond Global, 23 Sept. 2014 & USGS website \\
\hline
\end{tabular}

For morphometric analysis, topographical sheets are geometrically rectified and then geo-referenced using the Universal Transverse Mercator (UTM) coordinates system projection and the World Geodetic System (WGS84) datum considering the Ground Control Points (GCPs). The watershed area is delineated from SRTM DEM and topographical sheets of SoB using data preparation option of Erdas Imagine Software for marking the area of interest (AoI). Accordingly, Landsat 8 Satellite (December, 2014) image is used to produce and update the drainage maps, slope, land use/land cover etc. of watersheds using Spatial Analyst Tool of ARC GIS 10.2.

Quantitative analysis of the studied watersheds have been carried out for calculation and topology building of different morphometric parameters like basin area, perimeter, basin length, stream numbers, orders, frequency and bifurcation ratio; drainage density and texture; elongation and circularity ratio; form factor; relief and relief ratio; slope gradient; aspect; land use etc. The formulae used for calculation of morphometric parameters in the present study are given in Table 2. The calculated morphometric parameters of the watershed-I and II in the Barind Tract are given in Tables 3-6. The calculated area of the studied watershed-I and II of $1^{\text {st }}$ to $6^{\text {th }}$ order are 115 and $130 \mathrm{~km}^{2}$ respectively with respective perimeter values of 87 and $103 \mathrm{~km}$.

Table 2. Methodology adopted for computations of morphometric parameters.

\begin{tabular}{lll}
\hline Parameter & Formulae & References \\
\hline Stream order (U) & Hierarchical rank & {$[23]$} \\
Stream length $(\mathrm{Lu})$ & Length of the stream & {$[24]$} \\
Mean stream length $(\mathrm{Lsm})$ & Lsm $=\mathrm{Lu} / \mathrm{Nu}$ & {$[23]$} \\
Stream length ratio $(\mathrm{RL})$ & $R L=L u /(L u-1)$ & {$[24]$} \\
Bifurcation ration $(\mathrm{Rb})$ & $R b=N u / N u+1$ & {$[25]$} \\
Mean bifurcation ratio & $R b m=$ average of & \\
(Rbm) & bifurcation ratios of all & {$[23]$} \\
Drainage density (Dd) & orders & \\
Drainage texture (T) & $D d=L u / A$ & {$[24]$} \\
Stream frequency (Fs) & $F s=N u / A$ & {$[26]$} \\
Elongation ratio (Re) & $R e=D / L$ & {$[24]$} \\
Circularity ratio (Rc) & $R c=4 \pi A / P^{2}$ & {$[25]$} \\
Form factor (Ff) & $F f=A / L^{2}$ & {$[23]$} \\
Relief & $R=H-h$ & {$[24]$} \\
Relief ratio & $R r=R / L$ & {$[27]$} \\
\hline
\end{tabular}

\section{Results and Discussions}

\subsection{Morphometric Parameters}

\subsubsection{Stream Number (Nu) and Stream Orders $(W)$}

The stream ordering from the digitized streams of topo sheets and satellite images has been computed and ranked according to $[23,24]$. The order wise stream numbers $(\mathrm{Nu})$ and their linear characteristics are shown in Table 3. The studied watersheds show dendritic drainage pattern indicating homogenous subsurface strata. The $\mathrm{W}$ values vary from $1^{\text {st }}$ to $6^{\text {th }}$ orders stream and found that the total length of stream segment is maximum in $1^{\text {st }}$ order streams and decreases as the stream order increases. Drainage map along with stream order of the studied watersheds is shown in Figure 3.

In watershed-I and II the total $\mathrm{Nu}$ segments of different orders are 525 and 608 respectively with $408(77.77 \%)$ and $480(78.9 \%)$ of $1^{\text {st }}$ order; $91(17.3 \%)$ and $97(16.0 \%)$ of $2^{\text {nd }}$ order; $19(3.6 \%)$ and $22(3.6 \%)$ of $3^{\text {rd }}$ order; $4(0.8 \%)$ and 6 $(1.0 \%)$ of $4^{\text {th }}$ order; $2(0.4 \%)$ and $2(0.3 \%)$ of $5^{\text {th }}$ order; and 1 $(0.2 \%)$ and $1(0.2 \%)$ of $6^{\text {th }}$ order respectively. The highest percentage of $1^{\text {st }}$ order stream as $77.77 \%$ and $78.9 \%$ for watershed-I and II respectively indicates the possibility of flash flood after heavy rainfall [28] in downstream area of the Barind Tract i.e. floodplain area. The total length of streams in watershed-I and II area are 300 and $340 \mathrm{~km}$ respectively. The basin possesses dendritic drainage patterns, despite stream lengths and other hydrological properties are generally characterized by a treelike branching system with homogeneity and uniformity.

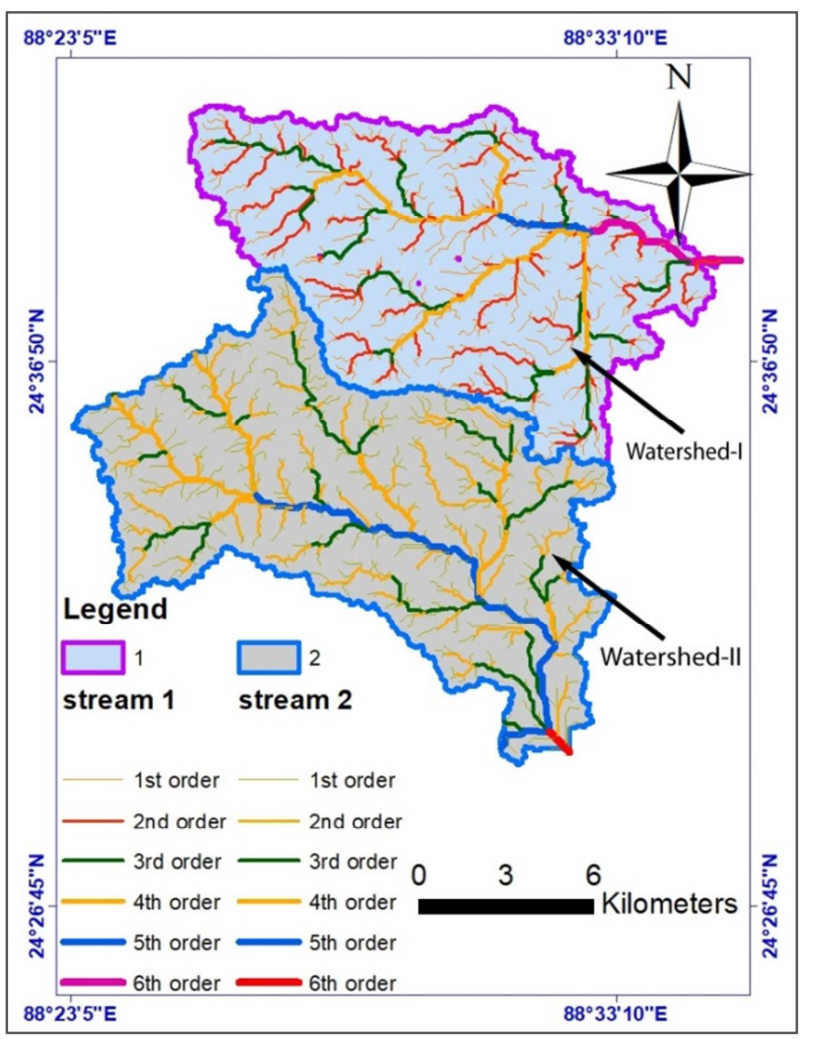

Figure 3. Drainage map with stream order of the Barind Tract, Bangladesh. 


\subsubsection{Stream Length (Lu), Mean Stream Length (Lsm) and Stream Length Ratio (RL)}

The stream length $(\mathrm{Lu})$, mean stream length (Lsm) and stream length ratio (RL) of the watersheds are computed after [24] and are given in Table 3. Generally, the total $\mathrm{Lu}$ segments decreases as the stream order increases indicating geometrical similarity between watersheds with increasing stream order and also reveals that streams of higher order have steep slopes and finer soil texture than that of lower order indicating low gradient [23].

\subsubsection{Bifurcation Ratio (Rb)}

The bifurcation ratio $(\mathrm{Rb})$ is the ratio of the number of stream segments of a given order to the number of segments of the next higher order. The characteristic $\mathrm{Rb}$ values of the studied watersheds range from 3.0 to 5.0 with mean values of 3.60 in both watersheds represent geology with reasonable homogeneity where the drainage pattern has not affected largely by structural disturbances [23]. The observed $\mathrm{Rb}$ is not the same from one order to its next order which is related to the geological and lithological development of the studied watersheds (Table 3).

Table 3. Linear aspect of the watersheds-I and II in the Barind Tract.

\begin{tabular}{|c|c|c|c|c|c|c|c|}
\hline & $\begin{array}{l}\text { Stream order } \\
(\mathrm{W})\end{array}$ & $\begin{array}{l}\text { No. of Streams } \\
\text { (Nu) }\end{array}$ & $\begin{array}{l}\text { Bifurcation } \\
\text { ratio (Rbf) }\end{array}$ & $\begin{array}{l}\text { Mean bifurcation } \\
\text { ratio (Rbm) }\end{array}$ & $\begin{array}{l}\text { Total length of } \\
\text { streams }(\mathrm{km})\end{array}$ & $\begin{array}{l}\text { Mean length of } \\
\text { Streams }(\mathrm{km})\end{array}$ & $\begin{array}{l}\text { Length ratio } \\
\text { (RI) }\end{array}$ \\
\hline \multirow{5}{*}{ Watershed-I } & I & 408 & & \multirow{5}{*}{3.60} & 163 & 0.40 & \\
\hline & III & 19 & 4.79 & & 35 & 1.84 & 2.43 \\
\hline & IV & 4 & 4.75 & & 24 & 6.00 & 3.26 \\
\hline & VI & 1 & 2.0 & & 6 & 6.00 & 4.00 \\
\hline & Total & 525 & 18.02 & & & & \\
\hline \multirow{6}{*}{ Watershed-II } & I & 480 & & \multirow{6}{*}{3.60} & 177 & 0.37 & 2.15 \\
\hline & II & 97 & 4.95 & & 77 & 0.79 & 2.40 \\
\hline & III & 22 & 4.41 & & 42 & 1.91 & 2.18 \\
\hline & V & 2 & 3.0 & & 18 & 9.00 & \multirow[t]{3}{*}{0.11} \\
\hline & VI & 1 & 2.0 & & 1 & 1.00 & \\
\hline & Total & 608 & 18.03 & & & & \\
\hline
\end{tabular}

\subsubsection{Drainage Density (Dd) and Drainage Texture (T)}

Drainage density (Dd) is an expression to indicate the closeness of channels and is a measure of the total length of the stream segment of all orders per unit area which is controlled by the slope gradient and relative relief of the basin [24]. A low drainage density value indicates permeable sub-surface strata and has a characteristic feature of coarse drainage, which generally shows values less than 5.0. Strahler (1964) [23] noted that low drainage density is favored where basin relief is low and vice versa. Smith (1950)
[26] classified Dd into five drainage texture (T) as: very coarse $(>2)$; coarse (2-4); moderate (4-6); fine (6-8); and very fine $(<8)$ and is given in Table 4.

Table 4. Drainage texture classification drainage density value [26].

\begin{tabular}{ll}
\hline Drainage Density (Dd) & Drainage Texture (Rt) \\
\hline Less than 2 & Very coarse \\
$2-4$ & Coarse \\
$4-6$ & Moderate \\
$6-8$ & Fine \\
Greater than 8 & Ultra-fine (bad land topography) \\
\hline
\end{tabular}

Table 5. Areal aspect of the watersheds-I and II in the Barind Tract.

\begin{tabular}{|c|c|c|c|c|c|c|c|c|c|}
\hline Watersheds & $\begin{array}{l}\text { Basin Area } \\
\left(\mathrm{km}^{2}\right)\end{array}$ & $\begin{array}{l}\text { Perimeter } \\
(\mathbf{k m})\end{array}$ & $\begin{array}{l}\text { Length } \\
(\mathrm{km})\end{array}$ & $\begin{array}{l}\text { Form } \\
\text { factor (Ff) }\end{array}$ & $\begin{array}{l}\text { Elongation } \\
\text { ratio (Re) } \\
\end{array}$ & $\begin{array}{l}\text { Circularity } \\
\text { ratio (Rc) }\end{array}$ & $\begin{array}{l}\text { Drainage } \\
\text { density (Dd) }\end{array}$ & $\begin{array}{l}\text { Stream } \\
\text { frequency (Fs) }\end{array}$ & $\begin{array}{l}\text { Drainage } \\
\text { texture }(T)\end{array}$ \\
\hline I & 115 & 87 & 19.44 & 0.304 & 0.118 & 0.2 & 2.61 & 4.57 & 6.03 \\
\hline II & 130 & 103 & 20.84 & 0.299 & 0.108 & 0.153 & 2.62 & 4.68 & 5.90 \\
\hline
\end{tabular}

The calculated values of Dd of the studied watershed-I and II are 2.61 and 2.62 respectively (Table 5) indicating weak permeable near surface lithology with moderate drainage and moderate relief. The values of $\mathrm{T}$ of the watershed-I and II are 6.03 and 5.90 respectively reveals the presence of resistant permeable lithology. The variation in $\mathrm{T}$ values depend on natural factors like climate, rainfall, vegetation, soil type and their infiltration capacity and relief of the watershed. The relationship between top soil lithology and hydrological analysis of the watersheds reveal moderate drainage density and generally represent semi-permeable or poor permeable surface soil lithology with moderate vegetation. The drainage density map of the watersheds is shown in Figure 4. 


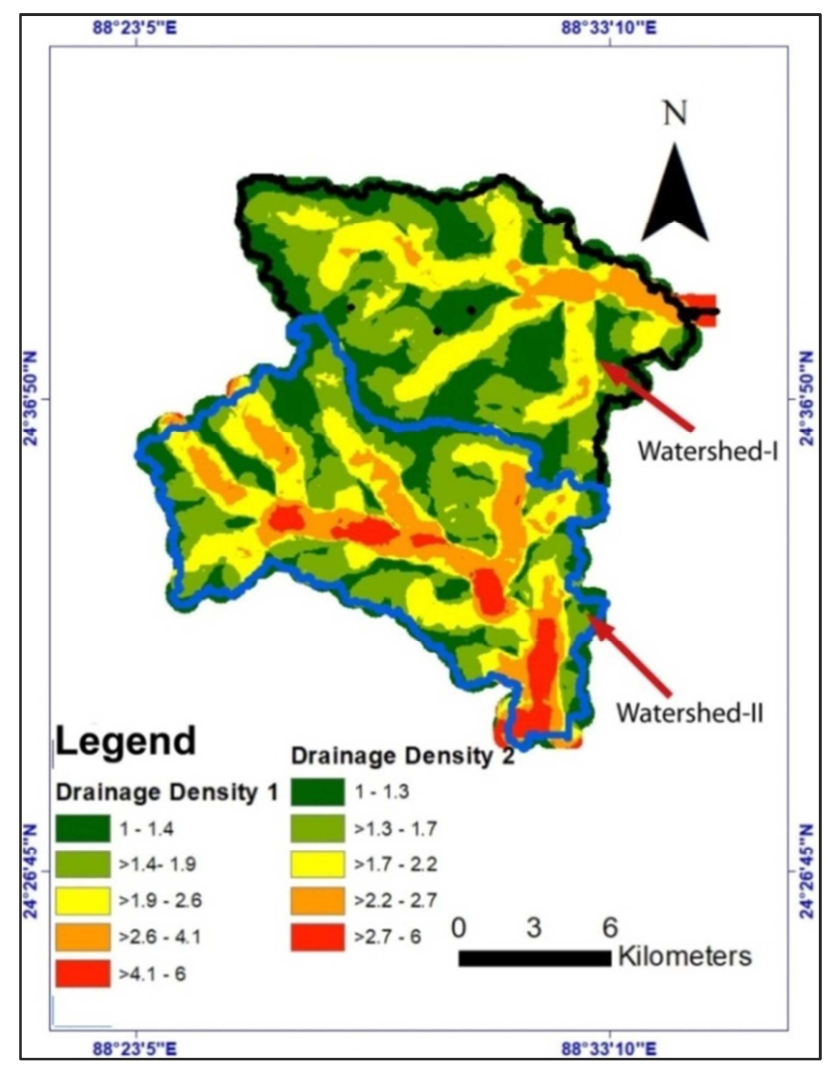

Figure 4. Drainage density map with stream order of the Barind Tract, Bangladesh.

\subsubsection{Stream Frequency (Fs)}

The stream frequency (Fs)/ channel frequency is the ratio of the total number of stream segments of all orders in the watershed to the total study area [24]. It represents different stages of landscape evolution where the occurrence of stream segments is related to surface soil nature, vegetation covers, rainfall pattern, physiography etc. The Fs values of the watershed-I and II are 4.57 and 4.68 respectively (Table 3) indicating positive correlation with the drainage density of the watersheds which suggest an increasing stream population occurring with respect to increase in drainage density of the watersheds.

\subsubsection{Elongation Ratio (Re)}

Elongation ratio $(\mathrm{Re})$ is defined as the ratio between the diameter of the circle of same area as the drainage basin and the maximum length of the watershed [25]. The values of Re generally range from 0.6 to 1.0 over a wide variety of climatic and geologic conditions where the values close to 1.0 are typical of very low relief area, and that of 0.6-0.8 are usually associated with high relief and steep ground slope [23]. These values can be grouped into three categories as: circular (>0.9); oval (0.9-0.8); and elongated $(<0.7)$. The Re values of the studied watershed-I and II are 0.118 and 0.108 which reveal that the watersheds have shape of elongated nature (Table 5) with low to moderate relief and surrounded by the area of moderate to steep slope due to areal topography.

\subsubsection{Circularity Ratio (Rc)}

Circularity ratio $(\mathrm{Rc})$ is the ratio of the watershed area to the area of circle having the same circumference as the perimeter of the watershed, and is influenced by the length and frequency of streams, geological structures, land use/land cover, climate, relief and slope of the watershed [29]. The low, medium and high values of the circulatory ratio are indications of respective youth, mature and old stages of the life cycle of the drainage basins. The Rc values of the watersheds-I and II area 0.20 and 0.15 respectively indicating youthful stage of watershed development (Table 5) with elongated shape and low discharge capacity of runoff. It also reveals the dendritic stage of drainage is mainly due to the variation of slope and relief pattern of the studied watersheds.

\subsubsection{Form Factor (Ff)}

Form factor $(\mathrm{Ff})$ defined as the ratio of watershed area to square root of the watershed length which indicates the flow intensity of a watershed for a particular area [24]. The long narrow watershed has larger lengths with smaller form factors. On the other hand, the circular shaped watershed has intermediate form factors, which are close to one. For perfectly circular watershed the Ff value will be greater than 0.78 , but short wide watershed have largest Ff value. The watersheds with high Ff values experience larger peak flows of shorter duration, whereas elongated watersheds with low Ff values experience lower peak flows of longer duration. The observed Ff values of the watershed-I and II are 0.30 and 0.29 respectively (Table 5) indicating elongated shaped watersheds along with low Ff values reveal flatter peak of runoff water flow for longer duration.

\subsubsection{Relief $(R)$ and Relief Ratio (Rh)}

The total relief $(\mathrm{R})$ is defined as the differences in elevation between the highest and the lowest points of a watershed. On the other hand, the relief ratio $(\mathrm{Rh})$ is the ratio of maximum relief to horizontal distance along the longest dimension of the watershed parallel to the principal drainage distance line [25]. The $\mathrm{R}$ and $\mathrm{Rh}$ values measure the overall steepness of the watershed which is an indicator of the intensity of the erosion process operating on the slope of the watershed. The $\mathrm{R}$ values of watershed-I and II are $32 \mathrm{~m}$ in both cases and that of $\mathrm{Rh}$ are 0.0004 and 0.0003 respectively which indicate that the major portion of the watersheds have gentle slope where the high relief of the watershed indicates the gravity flow of water, low infiltration and high runoff conditions (Table 6).

Table 6. Relief characteristics of the watersheds-I and II in the Barind Tract.

\begin{tabular}{lllll}
\hline Watersheds & Maximum height of basin (m) & Minimum height of basin (m) & Total relief (m) & Relief ratio \\
\hline I & 47 & 15 & 32 & 0.0004 \\
II & 47 & 15 & 32 & 0.0003 \\
\hline
\end{tabular}




\subsection{Aspect Map}

The aspect map represents the slope direction of watershed from higher to lower elevation and very much important to study the influence of sun light/ heat produced on local climatic condition. In the Barind Tract, the east-facing slope is comparatively less hot as it gets sun light before noon than that of west-facing slope with warmer climatic condition. So it has major effects on the distribution of vegetation type in the watershed area. The aspect map derived from SRTM DEM of the watersheds represents the compass direction of the aspect where 0 is true north and 90 aspect is the true east (Figure 5). The studied watersheds show east-facing slopes and therefore the slopes have higher moisture content along with higher vegetation.

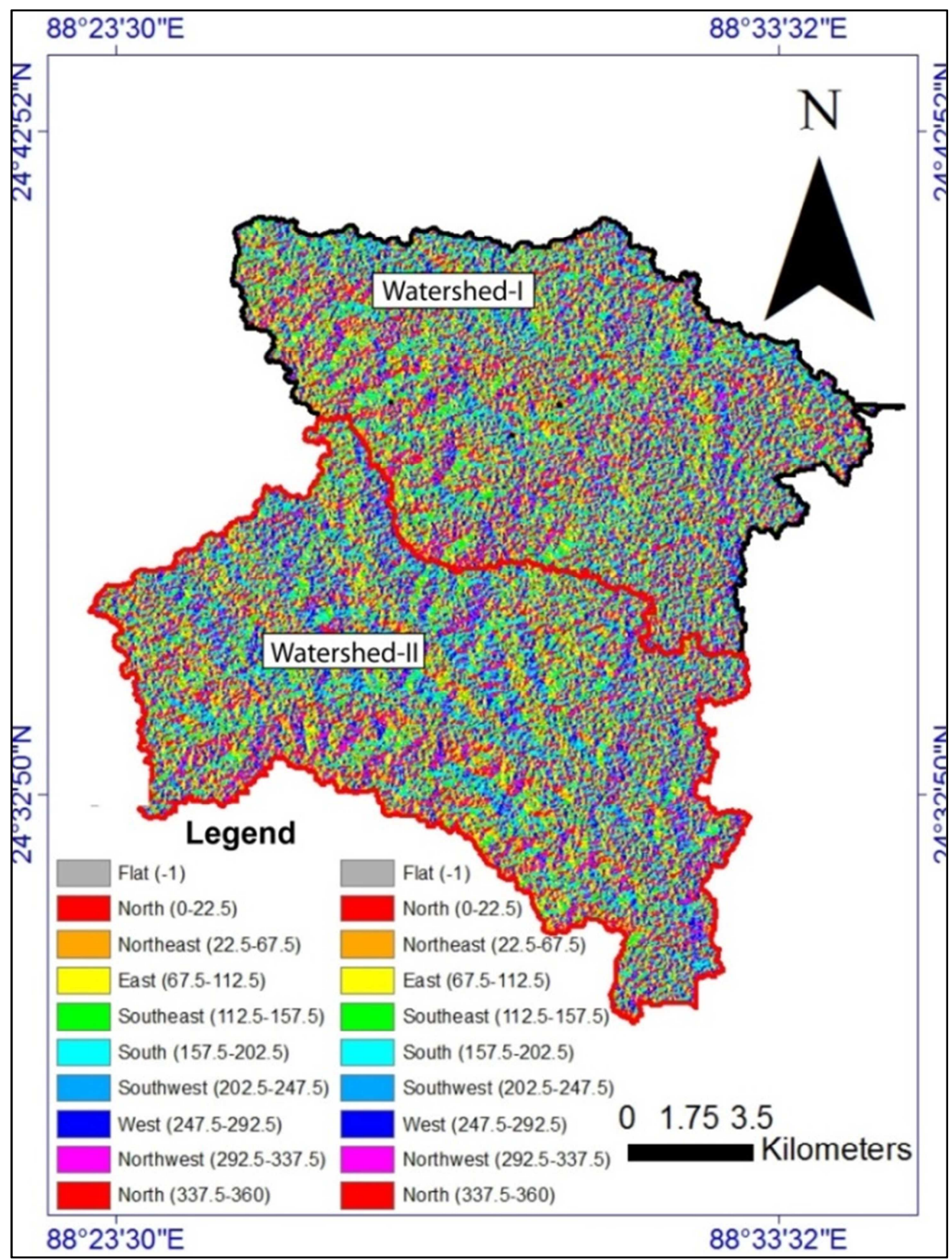

Figure 5. Aspect map of the Barind Tract, Bangladesh.

\subsection{Slope Map}

The slope measurement represents the change in surface value with respect to distance which can be expressed in degrees or percentage. In a raster format, the DEM is a grid where each cell is a value referenced to a common datum.
Any two points on the grid is sufficient to calculate slope where the maximum difference is found and the gradient is determined [30-32].

In the study, topographical elevation map for the Barind Tract is developed by DEM extracted from the SRTM data. Accordingly, the slope map of the watersheds is generated 
using ARC GIS spatial analyst tools. The slope of the area is important to control the run-off and hence the infiltration capacity of soil. Higher value of slope causes less infiltration of rainwater/ runoff water through top soil to recharge the groundwater in the aquifer.

The slope map is classified as: flat $\left(0-3^{\circ}\right)$; gentle $\left(3-<8^{\circ}\right)$; moderate $\left(8-<15^{\circ}\right)$; steep $\left(15-<30^{\circ}\right)$; very steep $\left(30-<50^{\circ}\right)$; and extremely steep $\left(\geq 50^{\circ}\right)$ (Figure 6) [33]. Accordingly, most of the area of the watersheds I and II come under flat to gentle slope with undulating nature and can be classified as 'good' category for its relevance for water resource management. This is favorable for the infiltration capacity with maximum time of percolation of runoff water. So the watersheds are potential for construction of check dams, percolation tank, artificial recharge of groundwater through the Managed Aquifer Recharge (MAR) technique etc.

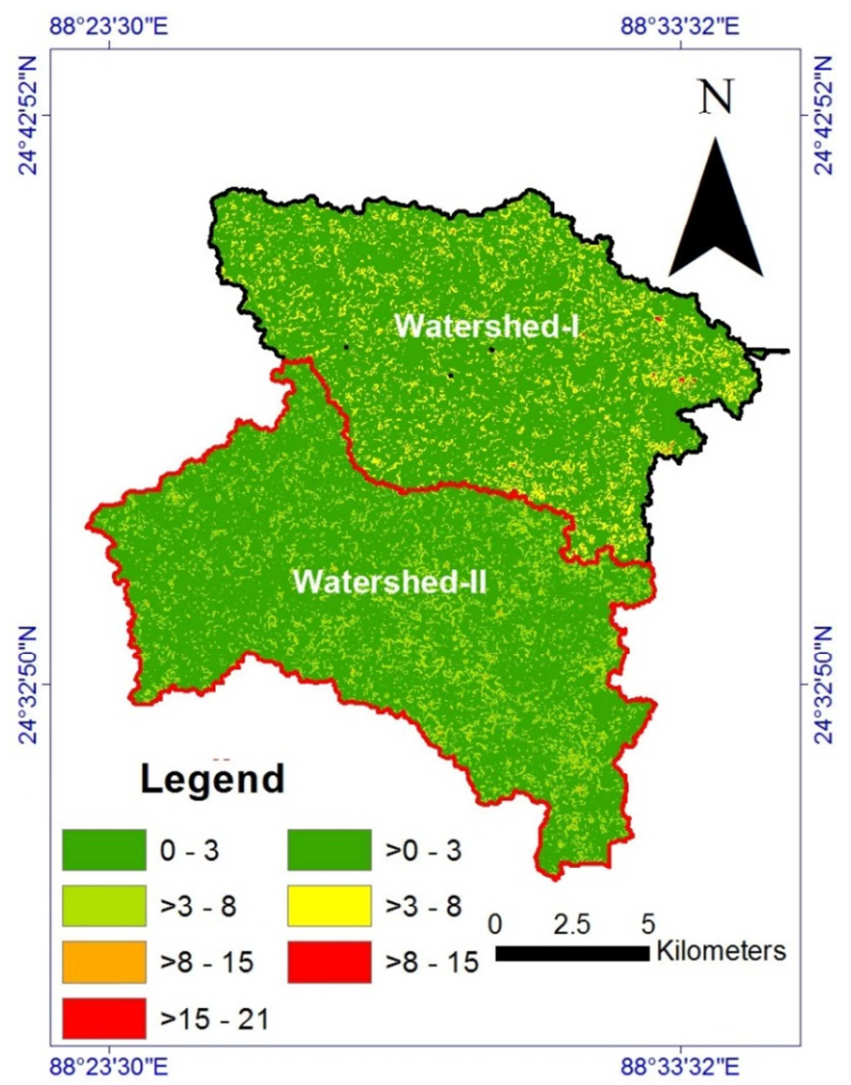

Figure 6. Slope map of the Barind Tract, Bangladesh.

\subsection{Land Use Pattern}

Land use pattern and its changes are most important factors for assessment of water resource of the watershed/ basin and reveals the utilization of land resource by manmade activities particularly agriculture and urbanization [34, 35]. Analyses of land use changes for hydrologic processes includes: changes in water demands from changing land use practices such as irrigation and urbanization; changes in water supply from altered hydrological processes of infiltration, groundwater recharge and runoff to understand the hydrological conditions of the watershed and their management etc. [36-39].
Table 7. Land use percent of the watersheds-I and II in the Barind Tract.

\begin{tabular}{llll}
\hline \multirow{5}{*}{ Watershed-I } & Land use category & Area $\left.\mathbf{( k m}^{\mathbf{2}}\right)$ & Percentage $\mathbf{( \% )}$ \\
\cline { 2 - 4 } & Settlement & 7 & 6.09 \\
& Cultivated Land & 105 & 91.30 \\
& Water body & 3 & 2.61 \\
& Total & 115 & 100 \\
& Settlement & 10 & 7.7 \\
& Cultivated Land & 118 & 90.8 \\
& Watershed-II body & 2 & 1.5 \\
& Total & 130 & 100 \\
\hline
\end{tabular}

In the present study, the land use pattern and their spatial variation is assessed from satellite data of Landsat-8 December, 2014 (30 m spatial resolution). A standard approach is applied for classification of the satellite image using Erdas Imagine 9.1 software starting from defining of the training sites, extraction of signatures from the image and then classification is performed. The land use pattern of the studied watershed-I and II reveal that major parts come under cultivated land $(91.30 \%$ and $90.8 \%$ respectively) which supports the need for future development and management for water resource (Table 7). Finally, the Maximum Likelihood Classification (MLC) method is applied and common land use categories are identified with reference to their water requirement i.e. cultivated land, settlement and water bodies (Figure 7).

\subsection{Relevancy of Water Resource Management with Morphometric Analysis}

Water resource management studies from land use pattern helps to understand the changing scenario of water demand from different activities such as agricultural requirement, domestic needs and industrialization. It can also be used to understand the infiltration, recharge and runoff rate of the watershed. The quantitative analysis of parameters of the watersheds based on remote sensing and satellite images derived from DEM have important role for water resource assessment like basin delineation; soil and water conservation and their management. Morphometric analysis of the watershed-I and II show elongated area with gentle slope. The site selection for rainwater/ runoff water harvesting by construction of check dams, percolation tank, artificial groundwater recharge structures etc. in the watersheds for water resource management have been assessed based on small-scale topographic maps using RS and GIS-based tools where morphometric analysis plays an important role. If this information is integrated with other hydrological characteristics of watersheds, the strategy of siting recharge and water-harvesting measures provides better water resource development and management plan.

The drainage patterns in the studied watersheds are dendritic in nature because of its weak permeable surface or near surface lithology with intermediate drainage and moderate relief. So the watershed areas are favorable for identification of water resource potential zones. The topographic elevation of the watersheds induce highest amount of rainwater/ runoff water from the elevated Barind Tract to the floodplain area with low elevation allows the 
higher amount of rainfall infiltration to recharge the aquifer zone.

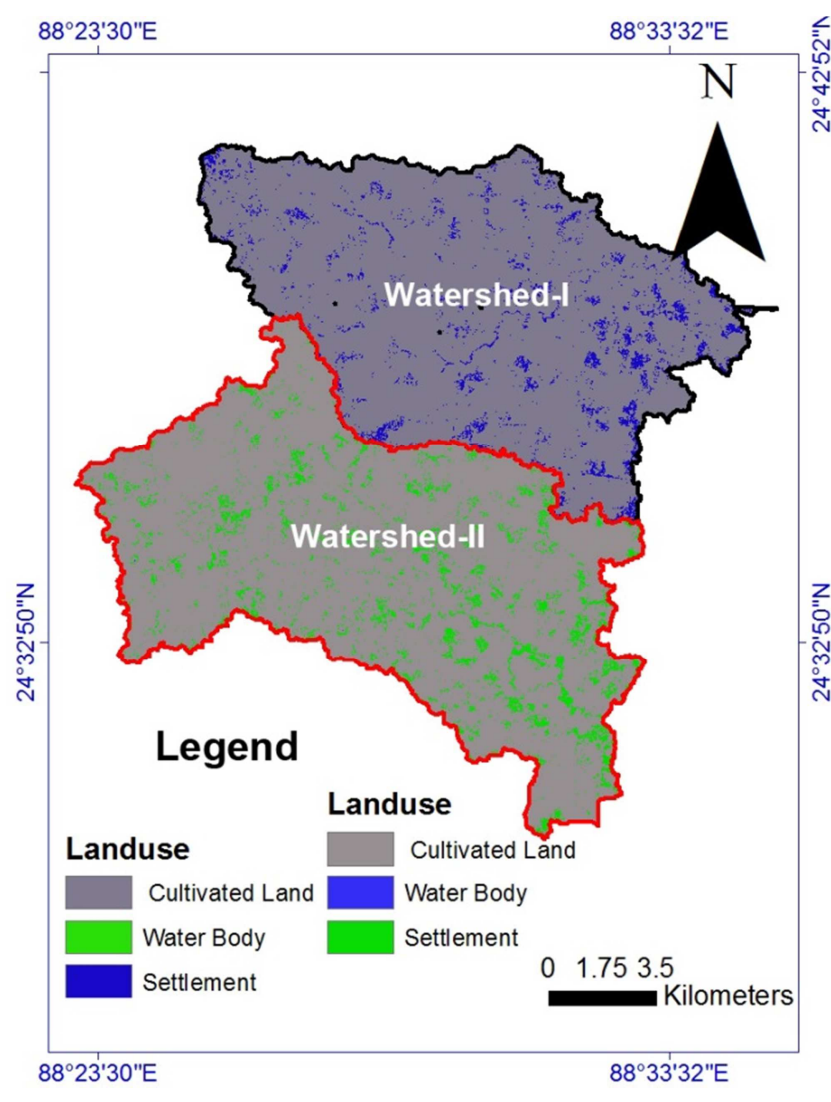

Figure 7. Land use/land cover map of the Barind Tract, Bangladesh.

\section{Conclusions and Recommendations}

For water resource management of the agro-based but drought prone Barind Tract, the morphometric analysis is carried out. The area is characterized by flash flood after rainfall in downstream. Here the dendritic drainage pattern has not affected largely by structural disturbance, but related to geological and lithological development of the area. The near surface lithology is characterized by poor permeable capacity with moderate drainage, relief and vegetation which is supported by the relationship between top soil lithology and hydrological analysis of the studied watersheds. Topographically the major part of the elongated watersheds have flat to gentle slope having long time for infiltration as flatter peak of runoff water flow prevail for longer duration. The area is bounded in the west by high relief of the Tract indicates the gravity flow of runoff water. As the basin is in youthful stage of development, it has low discharge capacity of runoff water. The dendritic drainage pattern represents variation in relief pattern of the watersheds. The east facing slopes of the watersheds reveal the higher moisture with higher vegetation. The flat to gentle but undulating slope of the watersheds are designated as good category for water resource management.

So the morphometric parameters reveal that groundwater recharge and surface water augmentation can be adopted for water resource management of the studied watersheds in the Barind Tract. It helps in better understanding of the drainage and basin planning and water resource management and will be useful for sustainable natural resource management and development at micro level by planners and decision maker. Subsequently, the morphometric parameters will be integrated with hydrological and hydrogeological data, and geophysical information, which will help to make decision regarding suitable sites for water conservation structure (e. g. check dam, percolation tank etc.) and artificial recharge of groundwater through MAR technique for groundwater development and management program. This study will provide a guideline to water resource managers in the Barind Tract by analyzing watershed morphometrically using RS and GIS techniques with an aim to improve the management approach in sustainable way.

\section{References}

[1] H Brammer, The Geography of the Soils of Bangladesh, $1^{\text {st }}$ Ed. The University Press Limited, 1996. p. 287.

[2] D Alexander, Changing perspectives on natural hazards in Bangladesh. Natural Hazards Observation, 1995, vol. 10 (1), pp.1-2.

[3] JP Morgan, WG McIntire, Quaternary geology of the Bengal Basin, East Pakistan and India. Geological Society of America Bulletin, 1959, vol. 70, pp.319-342.

[4] RA Khandoker, Origin of elevated Barind Madhupur areas, Bengal Basin: Results of neotectonic activities, Bangladesh Journal of Geology, 1987, vol. 6, pp.1-9.

[5] MS Alam, Paleoclimatic impact on the flood basin accretion and paleosol development in northwestern Bangladesh, Journal of Nepal Geological Society, 1998, vol.18, pp.227238.

[6] CS Jahan, ATMS Rahman, QH Mazumder, M Kamruzzaman, Adaptation for Climate Change Effect on Groundwater Resource through MAR Technique in Drought Prone Barind Area, Rural Bangladesh. In S. M. Ali (Ed.), Bangladesh: Combating Land Degradation and Drought. Dhaka: Series-II, Department of Environment (DoE), Ministry of Environment (MoEF), Government of Bangladesh. 2015, pp.61-83, ISBN 978-984-33-9991-5.

[7] CS Jahan, QH Mazumder, TMM Islam, Impact Evaluation of an Irrigation Project Based on Meteorological Data and Groundwater Hydrograph: A Case Study of BIADP, NW Bangladesh. 2008, Published in the Proceedings of the XXXIX IAH Congress (IAH 2008), Toyama, Japan, Held on 26 October to 1 November 2008.

[8] CS Jahan, M Ahmed, Flow of groundwater in the Barind area, Bangladesh: implication of structural framework. Journal of Geological Society of India, 1997, vol. 50, pp.743-752.

[9] CS Jahan, QH Mazumder, TMM Islam, MI Adham, Impact of Irrigation in Barind Area, NW Bangladesh - An Evaluation Based on the Meteorological Parameters and Fluctuation Trend in Groundwater Table. Journal of Geological Society of India, 2010, vol. 76, pp.134-142. 
[10] BMDA (Barind Multipurpose Development Authority), Project Proforma (rebound) for the Barind Integrated Area Development Project, Phase-II (4th revision), Barind Multipurpose Development Authority, Rajshahi, 2001.

[11] ATMS Rahman, CS Jahan, QH Mazumder, M Kamruzzaman, A Hossain, Evaluation of spatio-temporal dynamics of water table in NW Bangladesh - an integrated approach of GIS and statistics. Sustainable Water Resource Management, 2016, vol. 2 (3), pp.297-312, doi: 10.1007/s40899-016-0057-4

[12] CH Grohmann, Morphometric analysis in geographic information systems: applications of free software. Computers and Geosciences, 2004, vol. 30, pp.1055-1067.

[13] THJ Korkalainen, AM Lauren, TS Kokkonen, A GIS based analysis of catchment properties within a drumlin field. Boreal Environmental Research, 2007, vol. 12, pp.489-500.

[14] TK Hlaing, S Haruyama, MM Aye, Using GIS-based distributed soil loss modeling and morphometric analysis to prioritize watershed for soil conservation in Bago basin of lower Myanmar. Front Earth Science China, 2008, vol. 2, pp.465-478.

[15] A Javed, MY Khanday, R Ahmed, Prioritization of subwatershed based on morphometric and land use analysis using remote sensing and GIS techniques. Journal of the Indian Society of Remote Sensing, 2009, vol. 37, pp.261-274.

[16] A Pankaj, P Kumar, GIS based morphometric analysis of five major sub-watershed of Song River, Dehradun district, Uttarakhand with special reference to landslide incidences. Journal of the Indian Society of Remote Sensing, 2009, vol. 37 , pp.157-166.

[17] PD Sreedevi, PD Sreekanth, HH Khan, S Ahmed, Drainage morphometry and its influence on hydrology in a semi-arid region: using SRTM data and GIS. Environmental Earth Science, 2013, vol. 70 (2), pp.839-848.

[18] JB Ellis, DM Revitt, The management of urban surface water drainage in England and Wales. Water and Environment Journal, 2010, vol. 24, pp.1-8.

[19] NS Rao, Numerical scheme for groundwater development in a watershed basin of basement terrain: a case study from India. Hydrogeology Journal, 2008, vol. 17, pp.379-396.

[20] $\mathrm{J}$ Eyquem, Using fluvial geomorphology to inform integrated basin management. Water and Environment Journal, 2007, vol. 21, pp.54-60.

[21] DM Mark, Automatic detection of drainage networks from digital elevation models. Cartographica, 1984, vol. 21, pp.168178 .

[22] DG Tarboton, A new method for the determination of flow directions and contributing areas in grid digital elevation models. Water Resources Research, 1997, vol. 33, pp.309-319.

[23] AN Strahler, Quantitative geomorphology of drainage basins and channel networks. In: Te Chow, Ven. (Ed.), Hand Book of Applied Hydrology, McGraw Hill Book Company, New York, 1964.

[24] RE Horton, Erosional development of streams and their drainage basins: hydrophysical approach to quantitative morphology. Geological Society of America Bulletin, 1945, vol. 56 , pp.275-370.
[25] SA Schumm, Evolution of drainage systems and slopes in badlands at Perth Amboy, New Jersey. Geological Society of America Bulletin, 1956, vol. 67 (5), pp.597-646, doi:10.1130/0016-7606 (1956)67597.

[26] KG Smith, Standards for grading texture of erosional topography. American Journal of Science, 1950, vol. 248 (9), pp.655-668, doi:10.2475/ajs.248.9.655

[27] RF Hadley, SA Schumm, Sediment sources and drainage basin characteristics in upper Cheyenne River Basin. US Geological Survey, Water Supply Paper 1531-B, 198, 1961.

[28] C Chitra, P Alaguraja, K Ganeshkunari, D Yuvaraj, M Manivel, Watershed characteristics of Kundah sub basin using remote sensing and GIS technique. International Journal of Geomatics and Geosciences, 2011, vol. 2 (1), pp.311-335.

[29] VC Miller, A Quantitative Geomorphologic Study of Drainage Basin Characteristics in the Clinch Mountain Area, Virginia and Tennessee, Project NR 389042, Tech Rept 3. Columbia University Department of Geology, ONR Geography Branch, New York, 1953.

[30] PA Burrough, RA McDonnell, Principles of GIS. Oxford University Press, Oxford, UK, 1998, p.333.

[31] BHP Maathuis, Digital elevation model based on hydroprocessing. Geocarto International, 2006, vol. 21 (1), pp.21-26

[32] MK Jha, A Chowdhury, VM Chowdary, S Peiffer, Groundwater management and development by integrated RS and GIS: Prospects and constraints. Water Resource Management, 2007, vol. 21, pp.427-467.

[33] B Berhanu, AM Melesse, Y Seleshi, GIS-based hydrological zones and soil geo-database of Ethiopia. Catena, 2013, vol. 104, pp.21-31.

[34] YY Nian, X Li, J Zhou, LX Hu, Impact of land use change on water resource allocation in the middle reaches of the Heihe Basin in northwestern China. Journal Arid Land, 2014, vol. 6 (3), pp.273-286.

[35] P Singh, JK Thakur, S Kumar, UC Singh, Assessment of land use/land cover using Geospatial Techniques in a semi-arid region of Madhya Pradesh, India. In: Hakur, Singh, Prasad, Gossel (Eds.), Geospatial Techniques for Managing Environmental Resources. Springer and Capital Publication, Heidelberg, Germany, 2012, pp.152-163.

[36] L Sylla, D Xiong, HY Zhang, ST Bangoura, A GIS technology and method to assess environmental problems from land use/cover changes: Conakry, Coyah and Dubreka region case study. Egyptian Journal of Remote Sensing and Space Science, 2012, vol. 15, pp.31-38.

[37] JS Rawat, V Biswas, M Kumar, Changes in land use cover using geospatial techniques: A case study of Ramnagar town area, district Nainital, Uttarakhand, India. Egyptian Journal of Remote Sensing and Space Science, 2013, vol. 16, pp.111-117.

[38] PD Wagner, S Kumar, K Schneider, Assessment of land use change impacts on the water resources of the Mula and Mutha rivers catchment upstream of Pune, India. Hydrology and Earth System Science, 2013, vol. 17 (6), pp.2233-2246.

[39] P Singh, JK Thakur, UC Singh, Morphometric analysis of Morar River Basin, Madhya Pradesh, India, using remote sensing and GIS techniques. Environmental Earth Science, 2013, vol. 68, pp.1967-1977. 